\title{
Isolation and Identification Of Triterpenoid Saponin From Baringtonia asiatica Kurz Seeds
}

\author{
Meity N Tanor ${ }^{1}$, Abdul Latief Abadi², Bambang Tri Rahardjo², Jantje Pelealu ${ }^{3}$ \\ ${ }^{1}$ Doctoral Program, Faculty of Agriculture, University of Brawijaya, Indonesia \\ ${ }^{2}$ Lecturer of Plant Pest and Disease Major, Faculty of Agriculture, University of Brawijaya, Indonesia \\ ${ }^{3}$ Lecturer of Plant Pest and Disease Major, Sam Ratulangi University, Indonesia
}

\begin{abstract}
The study aimed to identify the content of the triterpenoid saponin compound from Barringtonia asiatica seeds collected from coastal of Malalayang beach, Manado, North Sulawesi. The method of extraction was the maceration with methanol solvent. The identification of the isolate was by thin layer chromatography, column chromatography, and GCMS. The phytochemistry test result of B. asiatica seed extract contained the compounds of alkaloid, saponin, and tannin. Then, the compound was separated by a thin layer chromatography method with a solvent system of methanol:chloroform:water. It produced three nodes that were spread around polar ( Rf 0.24), semipolar ( Rf 0.6) and non-polar ( Rf $0.78)$ areas. Meanwhile, the process of column chromatography could only separate two chemical components namely semipolar ( Rf 0.6) and polar (Rf 0.76). The identification with GCMS resulted in three compounds of Triterpenoid saponins, namely 2.4-bis-(1.1-dimethyl ethyl)-, methylcarbamate; 4Dodecylphenol; and 2.6 bis-(1.1-dimethylethyl)-4-methyl-, methylcarbamate.
\end{abstract}

Keywords: isolation, identification, triterpenoid, Baringtonia asiatica.

\section{INTRODUCTION}

Barringtonia asiatica is a kind of mangrove plant called "Sea Poison Tree" or "Fish Killer Tree." As its label says, this type of mangrove can instigate toxicity even death of fish which consume its seeds [5]. However, B. asiatica has many benefits. For example, its leaves are able to treat stomach ache and be anti-rheumatic medication. Also, its seeds are able to get rid of worms in the intestine [12], be antifungal [6], be anti-inflammation and analgesic [11], be anti-oxidant and antiplasmodial [9]. Thus, the plant is expected to contain a saponin compound.

Saponin is included as a natural compound with large molecule mass and value $[7,8,1,2]$. [10] state that saponin taken from Chenopodium quinoa seeds is pesticide and its work mechanism-

*Corresponding author:

Meity N Tanor

Doctoral Program, Faculty of Agriculture, University of

Brawijaya, Indonesia

E-mail:meitytanor@yahoo.co.id is not toxic. Therefore, the study to identify the content and the type of saponin resulted from $B$. asiatica seeds are significant. This information is required for the supply of raw material in producing economical bio-pesticide. Since B. asiatica grow in sandy and rocky aquaculture [12], this condition is mostly found in Indonesia.

\section{MATERIALS AND METHODS}

Formulating the crude extract of alkaloid, Saponin, Tannin dan Terpenoid tests

Samples of $B$. asiatica seeds was cleanly washed with running water and mashed with a blender. 450 grams of $B$. asiatica seed powder was macerated in a closed vessel for $3 \times 24$ hours and was occasionally shaken in a shaker containing methanol solvent. The solvent was filtrated by filter paper and was evaporated afterwards in a rotary evaporator within the temperature of $35-37^{\circ} \mathrm{C}$ (48-50 rpm). After that, we analyzed the content of alkaloid, flavanoid, and saponin based on [4]. 
Alkaloid Test was performed by adding 0.1 gram of the extract into $3 \mathrm{~mL}$ of chloroform and 3 drops of ammoniac. The chloroform fraction was separated and acidified by ten drops of $\mathrm{H}_{2}$ $\mathrm{SO}_{4} 2 \mathrm{M}$. The acid fraction, then, was added with Meyer and Wagner reagents. The presence of alkaloid was evident when the white deposit was made by Meyer reagent and the brown deposit by Wegner reagent.

Saponin Test was performed by putting 1 gram of extract into a beaker containing $100 \mathrm{~mL}$ of water, and was boiled for 5 minutes. Then, it was filtered, and the filtrate was tested. Ten $\mathrm{mL}$ of filtrate was incubated in a closed test tube for 10 minutes. The occurrence of saponin was identified when stable froth/foam formation was made.

Tannin test was performed by mixing 0.1 gram of extract with $2 \mathrm{~mL}$ of water and boiled for 3 minutes. It was filtered, and the filtrate was added with a drop of $\mathrm{FeCl}_{3} 1 \%$ (b/v). The dark blue or black colour exposed the existence of tannin.

Triterpenoid test was performed by giving 0.1 gram of extract to $2 \mathrm{~mL}$ of ethanol $30 \%$, heated and filtered. The filtrate was evaporated and added with eter by 1:1 ratio. The eter layer was added with Lieberman Burchard reagent (three drops of acetic acid anhydride and one drop of concentrated $\mathrm{H}_{2} \mathrm{SO}_{4}$ ). The red colour revealed the presence of triterpenoid.

\section{Analyses of Thin Layer Chromatography and Column Chromatography}

Thin Layer Chromatography was performed by following [13] method in which silica gel adsorbent coated plate and methanol:chloroform: water $(1: 1: 10)$ were treated as mobile phase. Then, its Retension factor (Rf) was calculated by dividing "the distance achieved by eluted compounds" with "the distance achieved by elution liquid." The column chromatography was performed by methanol: chloroform: water (1:1:10) solvent and silica gel column. The Rf analysis of column chromatography was tested by thin layer chromatography.

\section{Analysis of $G C$-MS}

The extraction result of saponin was analyzed by GC-MS to determineits structure. The GC-MS under following conditions: the injector tempera- ture was 305,000C; the carrier gas, helium (He), the speed of gas flow were $25,9 \mathrm{~cm} / \mathrm{sec}$; the pressure of carrier gas was $13,7 \mathrm{kPa}$; the column type was Rastek Rxi-5MS; the column temperature was $70,00 \mathrm{C}$; the ionization system was Electron impact (EI), and the ionization energy was $70 \mathrm{Ev}$.

\section{RESULTS AND DISCUSSION}

The result of $B$. asiatica seed extract produced brownish white, oily, semi-solid compound in the pasta form within the room temperature. The result of phytochemistry test by [4] method confirmed that the extract of $B$. asiatica seeds contained compounds of alkaloid, saponin, triterpenoid and tannin. From the test of Thin Layer Crhomatography, there were three nodes in the polar ( Rf score 0.24 ), semipolar ( Rf score 0.6), and nonpolar (Rf score 0.78 ) areas. On the other hand, the method of Column Chromatography could only separate two chemistry components concentrated in the semipolar ( $\mathrm{Rf}$ score 0.6 ) and polar (Rf score 0.76) areas (Table 1).

Table 1. The analysis result of B. asiatica seed extract based on Thin Layer Chromatography and Column Chromatography

\begin{tabular}{|c|c|c|}
\hline $\begin{array}{c}\text { Obtained } \\
\text { results }\end{array}$ & $\begin{array}{c}\text { Thin Layer } \\
\text { Chromatography }\end{array}$ & $\begin{array}{c}\text { Column } \\
\text { Chromatography }\end{array}$ \\
\hline Spot & 3 & 2 \\
\hline & 0,24 & 0,60 \\
Rf Score & 0,60 & 0,76 \\
\hline
\end{tabular}

The isolation and identification of triterpenoid saponin from the methanol extract of $B$. asiatica seeds with GCMS resulted in three Triterpenoid saponin compounds, namely 2.4-bis-(1.1-dimethylethyl)-, methylcarbamate; 4-Dodecylphenol; and 2.6 bis-(1.1-dimethylethyl)-4-methyl-, methylcarbamate (Table 2; Picture 1).

Table 2. The composition of triterpenoid compound in the methanol extract of B. asiatica seeds with GC-MS

\begin{tabular}{|c|c|c|c|}
\hline $\begin{array}{c}\mathrm{N} \\
\mathrm{o}\end{array}$ & $\begin{array}{c}\text { Retention } \\
\text { time } \\
\text { (minute) }\end{array}$ & $\begin{array}{c}\text { Abundance } \\
(\%)\end{array}$ & $\begin{array}{c}\text { The possibility of } \\
\text { compound name }\end{array}$ \\
\hline 1 & 14.300 & 2,61 & $\begin{array}{l}\text { 2.4-bis-(1.1-dimethyl } \\
\text { ethyl)-, methylcarbamate }\end{array}$ \\
\hline 2 & 18.850 & 1,13 & 4-Dodecylphenol \\
\hline 3 & 22.933 & 0,57 & $\begin{array}{l}\text { 2.6 bis-(1.1- } \\
\text { dimethylethyl)-4-methyl- } \\
\text { methylcarbamate }\end{array}$ \\
\hline
\end{tabular}




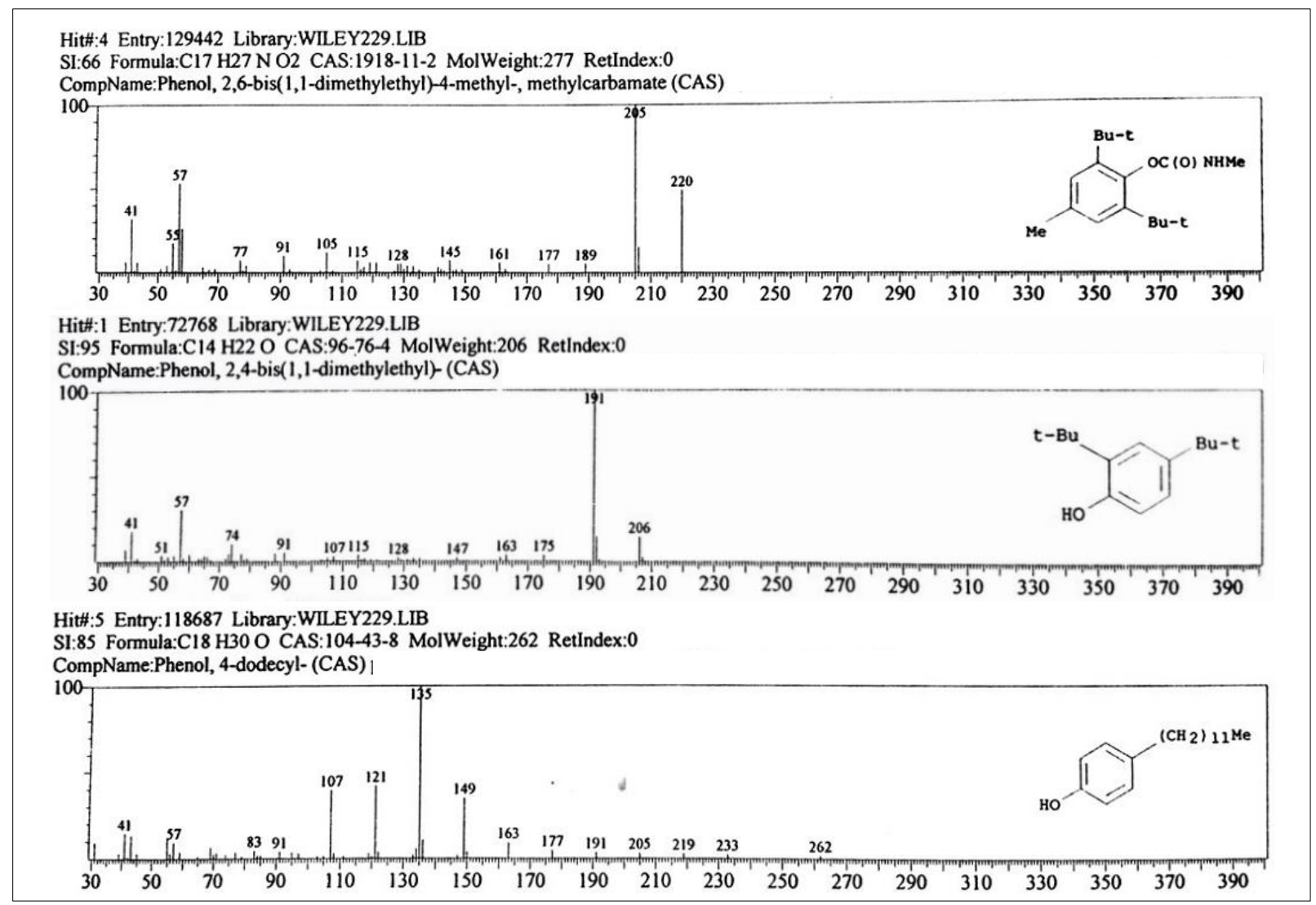

Picture 1. The GC MS result of methanol extract from B. asiatica seeds indicated three Triterpenoid saponin compounds

From these three compounds, the main component was 2.4-bis-(1.1-dimethyl ethyl)-, methylcarbamate that had the biggest abundance of $2.61 \%$ with $\mathrm{C}_{14} \mathrm{H}_{22} \mathrm{O}$ mo-lecule for-mula. Saponin consists of triter-pene glycoside and sterol which are identified within 90 plant families [4]. It is also common as a natural detergent found in various plants that have surfactant since it contains easily dissolved fat core and water. The component of saponin structure consists of hexose sugar with a number of carbon, hydrogen, and oxygen atoms [3]. Besides, it also can exterminate germs. [10] states that saponin taken from Chenopodium quinoa seeds is a bio-chemistry pesticide since it is produced directly from the extract of $C$. quinoa plant seeds and its work mechanism is not toxic.

\section{CONCLUSIONS}

Barringtonia asiatica seeds have three triterpenoid saponin compounds 2.4-bis-(1.1-dimethyl ethyl)-, methylcarbamate; 4-Dodecylphenol; and
2.6 bis-(1.1-dimethylethyl)-4-methyl-, methylcarbamate which are potential to be the biopesticide.

\section{REFERENCES}

1. Agrawal PK (1992) NMR Spectroscopy in the Structural Elucidation of Oligosaccharides and Glycosides, Phytochemistry. $3: 3307-3330$

2. Burger I, Burger BV, Albrecht CF, Spies HSC, Sandor P (1998) Triterpenoid Saponins from Becium grandiflorum var. obovatum, Phytochemistry. 49: 2087-2095

3. Cheeke PR (1999) Actual and Potential Applications of Yucca schidigra and Quilaja saponaria Saponin in Human and Animal Nutrition.http://www.asa.org/jas/syposia/prcee dings/0909.pdf. July 07, 2011.

4. Harborne (2006) Metode Fitokimia. Universitas Gajah Mada. Yogyakarta.

5. Hert AJ, Mander LN, Pongoh E, Rumampuk RJ, Tarigan P (2002) Two Major Saponins from Seeds of Barringtonia asiatica: Putative Antifeedants toward Epilachna sp. Larvae. Journal of Natural Products. 65: 115-120. 
6. Hussin, Muse NMR (2009) Antifungal Activity of Extracts and Phenolic Compounds from Barringtonia racemosa (Lecythidaceae). African Journal of Biotechnology. Vol 8. 12: 2835-2842.

7. Konoshima T, Yasudo T, Kashiwada Y, Cosentino LM, Lee KH (1995) Anti-aids Agents, 21.1 Triterpenoid Saponins as Anti-HIV Principles from Fruits of Gleditsia japonica and Gymnocladus chinensis, and a Structure-Activity Correlation, J. Nat. Prod.58. 9: 1372-1377

8. Nakanishi K (1974) Natural Products Chemistry, Vol. 1. Kodansha Scientific. Tokyo.

9. Ojewole JAO, Nirasha N, Clement A (2005) Molluscicidal, Cercariacidal, Larvicidal and Antiplasmodial Properties of Barringtonia racemosa Fruit and Seed Extracts. BLACPMA.Vol 3, No. 5.
10. Reilly SK, Hollis L, Jones RS, Peterson TA, Greenway D, King R (2007) Saponin of Chenopodium quinoa. Biopesticide Registration Action Document. U.S. Environmental Protection Agency, Canada.

11. Shikha P, Latha PG, Suja SR (2010) AntiInflammatory and Analgesic Activity of Barringtonia racemosa_Roxb. Fruits. Indian Journal of Natural Products and Resourced.Vol 1, No. 3: 356-361.

12. Tan R (2001) Sea Poison Tree Barringtonia asiatica.www.naturia.per.sg. May 03, 2012.

13. Matsjeh S (1999) Konversi Geraniol dari Minyak Sereh menjadi Pseudoionon dan Pembuatan Beberapa Senyawab Turunannya. Naskah Publikasi Pascasarjana Universitas Gajahmada, January 1st 1999. 